\title{
EGO DEPLETION AND ACADEMIC DISHONESTY IN STUDENTS COLLEGE DURING PANDEMI COVID-19
}

\author{
Herdian $^{1}$, Nadia Dwi Suci Ningtyas Putri ${ }^{2}$ \\ ${ }^{1,2}$ Universitas Muhammadiyah Purwokerto, Indonesia
}

\begin{abstract}
The COVID-19 pandemic is still being felt until September 2021 in several countries around the world. We examine the impact of the COVID-19 pandemic, especially on unethical behavior during online learningother phenomena such as ego depletion trigger academic dishonesty behavior that occurs. A total of 92 students participated in this research. The measurement tool uses the ego depletion scale and the academic dishonesty scale. The results show that ego depletion is a significant predictor of academic dishonesty. The contribution of ego depletion to academic dishonesty is 16.3\%. Ego fatigue makes students choose an easier academic path, which they feel has been affected by the COVID-19 pandemic. So that the behavior of academic dishonesty increases. The implications and research suggestions are discussed in detail.

Keywords: ego depletion, academic dishonesty, pandemic COVID-19, online learning, students college, cheating, plagiarism.
\end{abstract}

To cite this article:

Herdian \& Ningtyas Putri, N.D.S. (2021). Ego Depletion and Academic Dishonesty in Students College During Pandemi Covid-19. Education. Innovation. Diversity, 2(3), 6-13. DOI: https://doi.org/10.17770/eid2021.2.6715

\section{Introduction}

The ongoing COVID-19 pandemic until September 2021 in several countries still has a significant impact on human behavior. The results of many studies report that the COVID-19 pandemic has a lot of effect on mental health (Chaturvedi et al., 2021; Drissi et al., 2020; Herdian \& Chen, 2021; Kaparounaki et al., 2020). In particular, the impact of the COVID-19 pandemic was more significant on students than on workers, and women were more affected than men (Marelli et al., 2021). So this can cause changes in the daily activities of people around the world. We conducted a particular study of the impact of the COVID-19 pandemic on student activities. This is important to study because the COVID-19 pandemic has an impact on school closures around the world. During the COVID-19 pandemic, many studies reported that there was an increase in academic stress (Herdian \& Mildaeni, 2021), increased anxiety (Wang \& Zhao, 2020), sleep quality (Marelli et al., 2021), to an increase in unethical behavior. On student academics (Herdian et al., 2021). Referring to this impact, we conducted a follow-up study on unethical behavior such as academic dishonesty among college students. This is important to study because we think that the impact of the COVID-19 pandemic must be prevented as early as possible so that students can behave professionally in their academics.

Academic dishonesty behavior is a common thing in the academic environment. This refers to the number of studies on academic dishonesty in various countries in the world (Charubusp, 2015; Do Ba et al., 2017; Hendy \& Montargot, 2019; Herdian et al., 2021; Ismail \& Yussof, 2016; Lahur, 2004; Rawwas et al., 2004; Ruipérez \& García-Cabrero, 2016; Shalevska, n.d.) this happened not only during the COVID-19 pandemic but also before. Referring to the definition of academic dishonesty behavior, Kibler (1993) defines it as a form of academic cheating and plagiarism that involves students in giving or receiving unauthorized assistance in academic training or receiving money for work that is not done by themselves (Kibler, 1993). Typical forms of dishonesty are using inappropriate information during tests, 
cheating assignments, and submitting false information (including plagiarism) (Oran et al., 2015).

The factor of academic dishonesty has been widely studied, which is considered a factor of dishonesty during the COVID-19 pandemic is ego depletion. Ego depletion is critical to study as a predictor of academic dishonesty because the phenomenon is that students experience many significant changes in activity during the COVID-19 pandemic. Students must adopt online learning, which so far there has never been any prior training. In addition, the many tasks and academic burdens make students vulnerable to stress. So that, at the same time, will trigger the emergence of ego depletion. Ego depletion is a condition in which a person experiences a reduced desire or willingness to engage in action but is only temporary (Baumeister et al., 1998). For example, Lack of self-control, a result of ego depletion, reduces people's capacity to resist these self-serving temptations and consequently increases dishonesty (Gino et al., 2011). The results of a review of 48 recent studies on ego depletion in college students stated that undergraduate students were susceptible to the effects of ego depletion ( $92 \%$ significant), and that included various cognitive and emotional variables such as self-control, prospective memory, and anxiety (Gissubel et al., 2018). Students have many demands that require optimal self-control, such as completing lecture assignments, academic demands, adaptation to new environments, financial management, interpersonal conflicts, etc. Students who experience ego depletion in an experimental study conducted by Price \& Yates (2010) prefer to work on more straightforward questions. It can be concluded that ego depletion can affect the Lack of effort made on academic tasks. So that, in turn, will have an impact on unethical behavior. This research was conducted with a quantitative approach to examine the effect of ego depletion on academic dishonesty in college students.

\section{Theory}

Academic fraud is a fundamental problem for academic integrity in higher education (Brimble \& Stevenson-Clarke, 2005). Academic dishonesty is a violation of unethical behavior in the performance of academic assignments, which includes cheating, fabrication, plagiarism, and facilitating others to take actions in academic cheating (Pavela, 1997). Academic dishonesty is an act of fraud or cheating intended to obtain more than desired results on exams, papers, homework assignments, or other learning assignments (Miller et al., 2017). Academic dishonesty is motivated by many factors, including motivation (Siaputra, 2013; Thomas, 2017), religiosity (Khan et al., 2019), closer friendship, in students who have low grades (Griebeler, 2017), personal characteristics (Ruffle \& Tobol, 2017), Self-efficacy (Javed, 2020; Onu et al., 2019) parents' pressure (Punjab et al., 2017). Until now, research on academic dishonesty is still often investigated to see how this behavior occurs and understand it comprehensively. The aspect of academic dishonesty refers to forms of academic dishonesty that have been previously studied by McCabe \& Trevino (1993) and Stone et al. (2010), including cheating, collaboration, and plagiarism. Cheating is rule-breaking behavior related to the intention to gain an unfair advantage over a party or parties with whom the fraudster has a norm-regulated relationship (Green, 2004).

One of the predictors of academic dishonesty is ego depletion. Referring to the definition, Ego depletion is a condition when people have psychological and physical exhaustion, limited energy that affects cognitive problems, passive tasks become suboptimal and cause negative reactions and attitude problems (Undarwati et al., 2017). Ego depletion is theorized as a loss of self-control after being exercised over a period of time, leading to a loss of conscious regulation of behavior (Oehring, 2020). Ego depletion occurs when the power in self-control is depleted. Ego depletion is defined as a temporary state in which previous self-control reduces the individual's self-control resources (Hurley, 2019). that ego depletion is a consequence of 
exerting self-control on activities previously carried out, resulting in impaired self-control performance (Dang, 2018). Many factors that influence ego depletion include situational (Banker et al., 2017), cyberbullying(Zhang et al., 2021), personal demands, social demands, low self-control, task demands or too much burden, family problems, and conflicts with others. Others (Undarwati et al., 2017). Ego depletion can result in passive behavior such as Lack of initiative and impulsive behavior, such as decreasing mental control over behavioral responses (Vonasch et al., 2017), increasing students' deceptive behavior (Keller et al., 2020), and being a predictor of future anxiety (AlHarbi et al., 2021). In addition, the emergence of ego depletion can impact decreasing academic performance, concentration, leaving responsibility for tasks, and unethical behavior.

\section{Methodology}

A total of ninety-two students of the faculty of Islamic religion participated in this study. Based on demographic data, the female gender is $57(62 \%)$, and male is $35(38 \%)$. Students consist of semester $2(6.5 \%)$, semester $4(38 \%)$ semester $6(38 \%)$ semester $8(17.4 \%)$. Based on GPA, participants who have GPA 2.00-2.74 are 4.3\%, GPA 2.76-3.50 are 46.7\%, GPA 3.51-4.00 are $48.9 \%$. demographic information is shown in table 1.

\section{Table 1 Demographics of Participants}

\begin{tabular}{llrrr}
\hline & Levels & Counts & \% of Total & Cumulative \% \\
\hline sex & male & 35 & $38.0 \%$ & $38.0 \%$ \\
\multirow{3}{*}{ semesters } & female & 57 & $62.0 \%$ & $100.0 \%$ \\
& 2 & 6 & $6.5 \%$ & $6.5 \%$ \\
& 4 & 35 & $38.0 \%$ & $44.6 \%$ \\
& 6 & 35 & $38.0 \%$ & $82.6 \%$ \\
GPA & 8 & 16 & $17.4 \%$ & $100.0 \%$ \\
& $2,00-2,75$ & 4 & $4.3 \%$ & $4.3 \%$ \\
& $2,76-3,50$ & 43 & $46.7 \%$ & $51.1 \%$ \\
\hline
\end{tabular}

measurement

Academic Dishonesty

The scale developed by Ampuni et al. (2019) was compiled based on aspects of Academic Dishonesty according to McCabe \& Trevino (1993) and Stone et al. (2010), namely Cheating Collaboration and Plagiarism. Items totaled 11 favorable statements, using a Likert scale scoring 5 (often) to 1 (never). Example of a cheating statement item "Cheating on the test in any way", example of an item for collaboration "Allowing friends to copy my answers during the test". An example of an item for plagiarism is "Plagiarism partially or completely using the internet". The academic dishonesty scale shows high internal consistency $(\alpha=0.87)$.

\section{Ego Depletion}

The scale was developed by Undarwati et al. (2017), which is based on aspects of ego depletion, including psychological fatigue, physical exhaustion, helplessness, drained energy, cognitive impairment, passiveness, suboptimal, negative reactions, and behavioral disturbances. There are two types of statements used in this scale, namely Favorable and Unfavorable. The number of items on the ego-depletion scale is 30 . The Likert scale is 5 (very true of me) to 1 (very untrue of me). Examples of items used in this study include: "Give up to do anything, Tired of the situation, Tired with existing activities, Difficult to hold desire, Chest 
feels tight, Body feels weak, Head feels dizzy." The ego-depletion scale showed high internal consistency $(\alpha=0.743)$.

\section{Data Analysis}

We used correlation analysis to see the relationship between demographic variables with academic dishonesty and ego depletion variables. At the same time, the main analysis uses a simple linear analysis to see the effect of ego depletion as a predictor of academic dishonesty.

\section{Result and Discussion}

We conducted a correlation test to see the relationship between each variable and demographic data. The results are shown in Table 2. that sex correlates with academic dishonesty with a value of $\mathrm{r}=-0.364, \mathrm{p}<.001$. In addition, there is a significant positive correlation between ego depletion and academic dishonesty with a value of $r=0.403, p<.001$. This can be interpreted that the higher the ego depletion, the higher the academic dishonesty.

Table 2 Intercorrelation Among Demographic And Variables

\begin{tabular}{lccccc}
\hline & Sex & Semesters & GPA & $\begin{array}{c}\text { Academic } \\
\text { Dishonesty }\end{array}$ & $\begin{array}{c}\text { Ego } \\
\text { Depletion }\end{array}$ \\
\hline sex & - & & & & \\
Semesters & - & & & & \\
& $0.21 *$ & - & & & \\
GPA & 0.044 & - & & & \\
& $0.333 * *$ & 0.07 & - & & \\
Academic Dishonesty & 0.001 & 0.51 & - & - & - \\
\multirow{2}{*}{ Ego Depletion } & $-0.364 * * *$ & -0.058 & -0.074 & - & - \\
& $<.001$ & 0.582 & 0.486 & - & \\
& 0.029 & 0.07 & -0.014 & $0.403 * * *$ & - \\
\hline
\end{tabular}

Note. $* \mathrm{p}<.05, * * \mathrm{p}<.01, * * * \mathrm{p}<.001$

In table 3, the results of the statistical analysis of ego depletion regression on academic dishonesty show that ego depletion has a significant effect on academic dishonesty with a value of $F=17.5,<.001$. The value of $\mathrm{R}$ square shows that ego depletion contributes 0.163 or $16.3 \%$ to academic dishonesty. Meaning that ego depletion is a significant predictor of academic dishonesty. The line of regression equation for this research model is $\mathrm{y}=12,461+(0.252) \mathrm{x}$. So it can be interpreted that academic dishonesty will increase by 0.252 for every change in ego depletion.

\section{Table 3 Linear Regression Result}

\begin{tabular}{ccccccccc}
\hline & & & & \multicolumn{5}{c}{ Overall Model Test } \\
\cline { 5 - 8 } \multicolumn{1}{c}{ Model } & $\mathbf{R}$ & $\mathbf{R}^{2}$ & $\begin{array}{c}\text { Adjusted } \\
\mathbf{R}^{2}\end{array}$ & $\mathbf{F}$ & Estimate & B & $\mathbf{p}$ \\
\hline $\begin{array}{l}\text { Ego depletion to } \\
\text { academic dishonesty }\end{array}$ & 0.403 & 0.163 & 0.153 & 17.5 & 0.252 & 12.461 & $<.001$ \\
\hline
\end{tabular}

Our results confirm that ego depletion is a predictor of academic dishonesty behavior. This is following the research conducted by Keller et al. (2020) that ego depletion causes 
deceptive behavior in students. Ego depletion occurs because a lack of self-control, for example, reduces people's capacity to resist these self-beneficial temptations and consequently increases dishonesty (Gino et al., 2011). During the COVID-19 pandemic, students adapted to the online learning system. all devices must be provided to support the effectiveness of techniques in the implementation of online learning. Another impact arises when online learning is carried out. Students are required to have quite a lot of tasks and take up much time. Students have many demands that require optimal self-control, such as completing lecture assignments, academic demands, adapting to new environments.

The implication of this research is the policy of lecturers and campuses in providing various forms of academic assignments. Fatigue occurs when students experience many demands during online learning, on the other hand, students must adapt to the new system. In addition, this research contributes to the welfare of students during online learning, which needs to be considered. Because many policymakers or faculty staff may focus only on learning techniques because they need to adapt to online learning, this study has limitations that can be used as a basis for future research development. The many and diverse participants from all faculties may be considered so that the research results are more comprehensive.

\section{Conclusion}

The impact of the COVID-19 pandemic is still being felt by students. Along with the impact felt by students, online learning also impacts students' psychological power, so that ego depletion behavior appears, which in fact can increase students' academic dishonesty behavior. The results of our study contribute to the unethical behavior of students during online learning. Ego depletion proved to be a significant predictor of students' academic dishonesty. We hope that the student ego gets serious attention in online learning to handle the emergence of ego depletion behavior properly.

\section{References}

AlHarbi, B., Ibrahim, K., Al-Rababaah, J., \& Al-mehsin, S. (2021). The Ego Depletion and Its Relationship with the Future Anxiety among the University Female Students. International Journal of Higher Education, 10(2), 128-139.

Ampuni, S., Kautsari, N., Maharani, M., Kuswardani, S., \& Buwono, S. B. S. (2019). Academic Dishonesty in Indonesian College Students: an Investigation from a Moral Psychology Perspective. Journal of Academic Ethics. https://doi.org/10.1007/s10805-019-09352-2

Banker, S., Ainsworth, S. E., Baumeister, R. F., Ariely, D., \& Vohs, K. D. (2017). The Sticky Anchor Hypothesis: Ego Depletion Increases Susceptibility to Situational Cues. Journal of Behavioral Decision Making, 30(5), 1027-1040. https://doi.org/10.1002/bdm.2022

Baumeister, R. F., Bratslavsky, E., Muraven, M., \& Tice, D. M. (1998). Ego depletion: Is the active self a limited resource? Journal of Personality and Social Psychology, 74(5), 12521265. https://doi.org/10.1037/0022-3514.74.5.1252

Brimble, M., \& Stevenson-Clarke, P. (2005). Perceptions of the prevalence and seriousness of academic dishonesty in Australian universities. Australian Educational Researcher, 32(3), 19-44. https://doi.org/10.1007/BF03216825

Charubusp, S. (2015). Plagiarism in the perception of Thai students and teachers. Asian EFL Journal.

Chaturvedi, K., Vishwakarma, D. K., \& Singh, N. (2021). COVID-19 and its impact on education, social life and mental health of students: A survey. Children and Youth Services Review, 121, 105866. https://doi.org/10.1016/j.childyouth.2020.105866

Dang, J. (2018). An updated meta-analysis of the ego-depletion effect. In Psychological 
Research (Vol. 82, Issue 4, pp. 645-651). Springer Berlin Heidelberg. https://doi.org/10.1007/s00426-017-0862-x

Do Ba, K., Do Ba, K., Lam, Q. D., Le, D. T. B. A., Nguyen, P. L., Nguyen, P. Q., \& Pham, Q. L. (2017). Student plagiarism in higher education in Vietnam: an empirical study. Higher Education Research and Development, 36(5), 934-946. https://doi.org/10.1080/07294360.2016.1263829

Drissi, N., Alhmoudi, A., Al Nuaimi, H., Alkhyeli, M., Alsalami, S., \& Ouhbi, S. (2020). Investigating the Impact of COVID-19 Lockdown on the Psychological Health of University Students and Their Attitudes Toward Mobile Mental Health Solutions: TwoPart Questionnaire Study. JMIR Form Res, 4(10), e19876. https://doi.org/10.2196/19876

Gino, F., Schweitzer, M. E., Mead, N. L., \& Ariely, D. (2011). Unable to resist temptation: How self-control depletion promotes unethical behavior. Organizational Behavior and Human Decision Processes, 115(2), 191-203. https://doi.org/10.1016/j.obhdp.2011.03.001

Gissubel, K., Beiramar, A., \& Freire, T. (2018). The ego-depletion effect on undergraduate university students: A systematic review. Motivation and Emotion, 42(3), 334-347. https://doi.org/10.1007/s11031-018-9686-2

Green, S. P. (2004). Cheating. Law and Philosophy, 23(2), 137-185.

Griebeler, M. D. C. (2017). Friendship and in-class academic dishonesty. Economics Letters, 150, 1-3. https://doi.org/10.1016/j.econlet.2016.10.040

Hendy, N. T., \& Montargot, N. (2019). Understanding Academic dishonesty among business school students in France using the theory of planned behavior. International Journal of Management Education. https://doi.org/10.1016/j.ijme.2018.12.003

Herdian, H., \& Chen, Q. (2021). Mental Health in the Elderly during the Pandemic in Indonesia. Journal of Clinical \& Developmental Psychology.

Herdian, H., \& Mildaeni, I. N. (2021). Academic Stress On Muslim Students In Indonesia: Study On Online Learning. Revista EDUCARE-UPEL-IPB-Segunda Nueva Etapa 2.0, 25(1), 224-239.

Herdian, H., Mildaeni, I. N., \& Wahidah, F. R. (2021). "There are Always Ways to Cheat" Academic Dishonesty Strategies During Online Learning. Journal of Learning Theory and Methodology, 2(2), 60-67.

Hurley, P. J. (2019). Ego Depletion and Auditors' JDM Quality. Accounting, Organizations and Society, 77, 1-41. https://doi.org/10.1016/j.aos.2019.03.001

Ismail, S., \& Yussof, S. H. (2016). Cheating behaviour among accounting students: some Malaysian evidence. Accounting Research Journal, 29(1). https://doi.org/10.1108/ARJ05-2014-0050

Javed, A. (2020). Predicting the Underlying Factors of Academic Dishonesty by University Students: A Case Study. SSRN Electronic Journal. https://doi.org/10.2139/ssrn.3576062

Kaparounaki, C. K., Patsali, M. E., Mousa, D.-P. V, Papadopoulou, E. V. K., Papadopoulou, K. K. K., \& Fountoulakis, K. N. (2020). University students' mental health amidst the COVID-19 quarantine in Greece. In Psychiatry research (Vol. 290, p. 113111). https://doi.org/10.1016/j.psychres.2020.113111

Keller, T., Kiss, H. J., \& Szamado, S. (2020). Cheating in Primary School : Experimental Evidence on Ego- Depletion and Individual Factors. Centre for Economic and Regional Studies, 1-37.

Khan, I. U., Khalid, A., Hasnain, S. A., Ullah, S., Ali, N., \& Zealand, N. (2019). The Impact of Religiosity and Spirituality on Academic Dishonesty of Students in Pakistan. European Online Journal of Natural and Social Sciences.

Kibler, W. L. (1993). Academic Dishonesty: A Student Development Dilemma. NASPA Journal, 30(4), 252-267. 
Lahur, A. (2004). Plagiarism among Asian students at an Australian university offshore campus: Is it a cultural issue? A pilot study. Proceedings of the HERDSA Conference.

Marelli, S., Castelnuovo, A., Somma, A., Castronovo, V., Mombelli, S., Bottoni, D., Leitner, C., Fossati, A., \& Ferini-Strambi, L. (2021). Impact of COVID-19 lockdown on sleep quality in university students and administration staff. Journal of Neurology, 268(1), 815.

McCabe, D. L., \& Trevino, L. K. (1993). Academic dishonesty: Honor codes and other contextual influences. Academic Ethics, 1546(July), 545-562. https://doi.org/10.4324/9781315263465-43

Miller, A. D., Murdock, T. B., \& Grotewiel, M. M. (2017). Addressing Academic Dishonesty Among the Highest Achievers. Theory into Practice, 56(2), 121-128. https://doi.org/10.1080/00405841.2017.1283574

Oehring, D. (2020). Prayer as a Potential Buffer Against Ego Depletion [Georgia Southern University]. https://digitalcommons.georgiasouthern.edu/etd/2118

Onu, D. U., Onyedibe, M. C. C., Ugwu, L. E., \& Nche, G. C. (2019). Relationship between religious commitment and academic dishonesty: is self-efficacy a factor? Ethics and Behavior. https://doi.org/10.1080/10508422.2019.1695618

Oran, N. T., Can, H. O., Senol, S., \& Hadimli, A. P. (2015). Academic dishonesty among health science school students. Nursing Ethics. https://doi.org/10.1177/0969733015583929

Pavela, G. (1997). Applying the power of association on campus: A model code of academic integrity. $J C \& U L, 24,97$.

Price, D. A., \& Yates, G. C. R. (2010). Ego depletion effects on mathematics performance in primary school students: why take the hard road? Educational Psychology, 30(3), 269281.

Punjab, P., Quraishi, U., \& Aziz, F. (2017). Academic Dishonesty at the Higher Education Level in. In JRRE.

Rawwas, M. Y. A., al-Khatib, J. A., \& Vitell, S. J. (2004). Academic Dishonesty: A CrossCultural Comparison of U.S. and Chinese Marketing Students. Journal of Marketing Education, 26(1), 89-100. https://doi.org/10.1177/0273475303262354

Ruffle, B. J., \& Tobol, Y. (2017). Clever enough to tell the truth. Experimental Economics, 20(1), 130-155.

Ruipérez, G., \& García-Cabrero, J. C. (2016). Plagiarism and academic integrity in Germany. Comunicar, 24(48), 9-17. https://doi.org/10.3916/C48-2016-01

Shalevska, E. (n.d.). Cheating And Academic Dishonesty And Covid-19 Distance Learning2. Bitola, May 2021, Vol. 21, 18.

Siaputra, I. B. (2013). The 4PA of plagiarism: A psycho-academic profile of plagiarists. International Journal for Educational Integrity, 9(2). https://doi.org/10.21913/IJEI.v9i2.892

Stone, T. H., Jawahar, I. M., \& Kisamore, J. L. (2010). Predicting academic misconduct intentions and behavior using the theory of planned behavior and personality. Basic and Applied Social Psychology, 32(1), 35-45. https://doi.org/10.1080/01973530903539895

Thomas, D. (2017). Factors That Explain Academic Dishonesty Among University Students in Thailand. Ethics and Behavior, 27(2), 140-154. https://doi.org/10.1080/10508422.2015.1131160

Undarwati, A., Mahabati, A., Khaerani, andewi cahaya, Hapsari, ayu dyah, Kristanto, andreas agung, Stephany, endah sasmitohening, \& Prawitasari, johana endang. (2017). Pengukuran Ego Depletion Berbasis Indigenous Psychology. Intuisi Jurnal Psikologi Ilmiah, 9(1), 26-38.

Vonasch, A. J., Vohs, K. D., Pocheptsova Ghosh, A., \& Baumeister, R. F. (2017). Ego Depletion Induces Mental Passivity: Behavioral Effects Beyond Impulse Control. 
Motivation Science, 3(4), 321-336. https://doi.org/10.1037/mot0000058

Wang, C., \& Zhao, H. (2020). The impact of COVID-19 on anxiety in Chinese university students. Frontiers in Psychology, 11, 1168.

Zhang, Z., Xiao, H., Zhang, L., \& Zheng, J. (2021). Linking Cyberbullying to Job Strain: Roles of Ego Depletion and Self-Efficacy. Journal of Aggression, Maltreatment \& Trauma, 118. 